University of Louisville

ThinkIR: The University of Louisville's Institutional Repository

Electronic Theses and Dissertations

1942

\title{
The incidence of Trichinella spiralis in the diaphragms of swine from the Louisville abattoirs.
}

Stuart Lyle Adams

University of Louisville

Follow this and additional works at: https://ir.library.louisville.edu/etd

Part of the Animal Sciences Commons, and the Biology Commons

\section{Recommended Citation}

Adams, Stuart Lyle, "The incidence of Trichinella spiralis in the diaphragms of swine from the Louisville abattoirs." (1942). Electronic Theses and Dissertations. Paper 1657.

https://doi.org/10.18297/etd/1657

This Master's Thesis is brought to you for free and open access by ThinkIR: The University of Louisville's Institutional Repository. It has been accepted for inclusion in Electronic Theses and Dissertations by an authorized administrator of ThinkIR: The University of Louisville's Institutional Repository. This title appears here courtesy of the author, who has retained all other copyrights. For more information, please contact thinkir@louisville.edu. 
UNIVERSITY OF LOUISVILIE

THE INCIDENCE OF TRICHINELIA SPIRALIS IN THE DIAPHRAGMS OF SWINE FROM THE LOUISVILIE ABATTOIRS

\author{
A Dissertation \\ Submittod to the Faculty \\ of the Graduate School of the University of Loulsville \\ in Partial Fulfiliment of the \\ Requirements for the Degree \\ of water of Sclence
}

Department of Bacterlology

by

Stuart Iylo Adams

Yoar

1942 
NATE OH STUDEMT: Stuart [y] Adams

TITLE OF THESIS: The Incidence of Irichinella Spiralis in The Jiaphragms of Svine From the Louisville Abattoirs

APPROV BY REDING COALITUS COMPOSED OF THE FOLLOUTH IHABES:

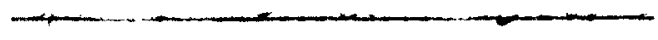

NAME OF DIRECTOR:

DAT: April $2 x_{1} 1942$ 


\section{ACKNOWLEDGEMENT}

I am Indebted to Dr. J. A. Kennedy for his holpful oriticism and direction, to Nr. Arthur Novak who prepared the IIlustrations and to Joseph E. Seagram \& Sons, Inc. for the use of their laboratory faclilties. 
TABLE OI CONPENTS

Page No.

I Introduetion and History

1

II Survey of Methods

6

III Adaptation of Methods

10

IV Results and Discussion

12

V Summary

15

VI References 
INTRODUCTION AND HISTORY 
Trichinosis is a disease ceused by the parasitic nematode Trichinelia spiralis. When meat containing encysted larvae is consumed the oysts are dissolved by the action of the gastric juice in the stomach and the larvae migrate to the intestine where they mature, copulate and give birth to living young within a wook of the original infection. The larvae enter the lymph spaces and are carried to the thoracic duct from which they roach the venous c1rculation and thence the arterial clrculation by way of the heart and the pulmonary capillaries. From the arterial blood the larvae enter most of the striated muscles. After entering the mascle fibers the larvae grow rapidly, become spirally colled, and in 4 to 6 woeks a mombranous capsule begins to form around each worm. If the infested host remins alive, the cyst wall usually begins to calcify in 8 to 10 months. Eventualiy the entire cyst becomes calcified and the larvae die.

The presence of encysted trichine larvae in the mascles of man was probably first noted by Tiedemann in 1822, although he failed to recognize thelr significance. John Hilton in 1833 was the first to suggest the parasitic nature, although the actual discovery of the worm was made in 1835 by James Paget who saw the calcifled larvae in cadavers at st. Bartholomew's Hospital and found upon microscopic examination that they conteined a colled roundworm. Paget's discovery was reported by his teacher, Robert owen, who called the parasite, Triehritarsplarty. 
Luckart in 1855 and virchow in 1859 proved that larvae fed to hogs developed to adults in the host, Invaded the macosa and leter oncyated in the striated muscle. Zenker in 1860 was the first to recognize the phys10logicel syptoms of trichinosis when he found both adult and larral forms in a ch11d who had died of what was thought to be typhosd ferer. It was zenker who proved that the rorm was capable of causing a serlous disease and was not merely a harmless invader. Nany animals including man, swine, rats, dogs, cats, bears, and birds have been found to be infected with Prientnella siveris, However, human infestation is almost entirely due to swine since none of the other naturally infested animals are commonly eaten by man.

Zenker's discovery of the pathogeniclty of trichinae infestation coupled with Leidy's discorery of trichinae in pork focused attention upon swine as the source of human infestation. A "Medical Annotation" in the Iancet (1866) states that Professor Virchov, addressing a meeting of town councellors, butchers, doctors and laymen at Berlin in 1865 urged that microscopic examination of pork be inaugurated. He then handed the chalrman of the meeting a plece of smoked sausage and a piece of mat from a trichinous pig. Uxwan, a veterinarian, contended that trichinae were harmless and to prove his point ate some of the infested sausage. He developed a severe case of trichinosis five days later and the furor aroused caused the butchers of Beriln to adopt microscopic examination of all pork in December, 1865. This was the first concerted attempt at control of trichinosis. 
The relation of type of feed to incidence of infestation in swine was recognized by Mark (1889). In 1881 he examined 500 hogs from Chlcago and found 2 per cent positive. These were a mixture of garbage and grain fed hogs. In 1888 he completed a study of 3,064 of fal and garbage fod hogs from Boston and found that 12.86 per cent were infested with trichinae. In another group of 234 garbage fed hogs he found 17.95 per cent had trichinae. The procedure followed by lark was the direct microscoplc examination of 1 grain of diaphragm mascle. From a consideration of the results of his own surveys and the surveys conducted by other parasitologists kark concluded thet the type of food was the most important factor in the incidence of trichinosis in swine. He stated that a high rate of infestation was due to the feoding of garbage, offal, or any foed containing uncooked meat scraps.

De Pletra santa (1884) in a study of trichinosis in the United stetes grouped the results of a muber of surreys according to the type of feed received by the swine examined.

Apparently Pasture Raised Silne - 100 from Indiana, no positives (Detmers, 1883)

Southern swine - 4146 southern swine, no positives; 241 Irom Louisville, Ky., 0.83 per cent pos1tive; 5400 from New Orleans, 0.4 per cent positive (Deverson, 1881); 30 from Atlante, Ga., no positives (Simpson, ante 1884); 180 from Nashvilie, Tenn., no positives (steger ante 1884); 330 from San Antonio, Texas, 0.6 per cent positive (Meyers ante 1884). 
Grain Fed Swlne - At Chicago, IIl., 2 por cont positive (Atwood and Belf1eld, 1886); 3331 from Chicago, Ill., 2.4 per cent positive (Detmers, 1883).

ApparentIy Garbage Fed, Offal and Grain Fed Mixed Irom Dearborn County, Ind, in 1874, 16.3 per cent positive and betweon $1874-1884,6.5$ per cent positive (Harding and Robbins ante 1884); 8773 from Boston, Mass., 4.0 per cent positive (BIIIings, $1879-81$ ): 529 from St. Louls, Mo., 3.4 per cent positive (Deverson, 1881).

Calvin (1890) reported that approximately 8 - 10 per cent of the swine in Iowa fed on slaughterhouse offal were infested with trichinae while the grain fod hogs were practically free of trichinosis.

During the 15 jears from 1891 - 1906 the United Stetes required that all export pork be examined microscoploally for trichinosis. of $8,257,928$ diaphragms examined between 1898 and 1906 approximately 1.5 per cent were found to be infested with living trichinae larrae. An aditional 1 per cent were found to contain dead trichinae or bodies that resembled trichinae.

Schwartz has reported the examination of 25,000 diaphragms during the Jears 1933 - 38. The average incidence of infestation in 13,000 farm ralsed hogs was 0.95 per cent and in 10,300 garbage fed hogs was 5.7 per cent. The digestion method of examination was employed.

Hobmaler and Gelger (1938) in a survey of trichinosis of swine at san Franc1sco found 1.4 per cent of 92 garbage fed hogs contained trichinosis but found no trichinae in 108 hogs with unkmown type of feed. The digestion method was used. 
Barrett and Sears (1938) reported 194 Michigan swine examined by the digestion method with no positives.

Cameron (1938 - 40) has published three reports of the incidence of trichinosis in canada as determined by the digestion technlque. In the first report 729 hogs had been examined and 2.06 per cent were found positive. In the next year he found an incidence of infection of 0.75 per cent in 2,000 hogs and in the third group studied only 0.2 per cent of the 995 hogs were infested.

Hood and 01sen (1939) examined 500 grain fod hogs by the digestion method and found 0.4 per cent positive. Kerr and Jacobs (1940) reported an incidence of 0.5 per cent in 566 grain fed hogs, 6.0 per cent in 502 garbage Iod hogs and 1.0 per cont in 1532 hogs with mixed and unknown feed.

McNaught and Zapata (1941) examined 495 garbage fed hogs at San Francisco by both the microscopic and digestion methods and found 4.04 per cent positivo.

Although there heve been numerous reports on the incldence of trichinosis in swine in the United States, a study of all avaliable data Indicates that the incidence varies greatiy with the locality and the prodominant type of feoding. For this reason it was considered important to obtain data on the incidence of trichinosis in swine slaughtered in Jefferson County, Kentucky. 
SURVEY OF METHODS 
There are three methods which have been used extensiveIf for the detection of trichinae infestation, the direct microscopic mothod, the digestion-Beerman mothod and the intradermal test.

\section{Direct Microscopic Technique}

The direct microscop1c techntque consists of placing small pleces of the mascle to be examined between two glass plates, pressing the plates together so that a uniform transparency of the muscle fibers is obtained and examining under the microscope with the low power objective. The trichinae press most cormoniy used at present is the one described by Nolan Bozicerlch (1938). It consists of two glass plates approximately $83 / 4$ inches long by 2 inches wide and $\frac{x}{4}$ inch thlok which are pressed between two motal frames by four bolts and nuts. This press differs from the one described by Hall and Collins (1937) and previously used by the mojority of workers in this fleld only in that the earlier type was Iitted with two bolts and nuts instead of four. The four bolt arrangement is sald to give a more uniform transparency of the fibers.

There has been considerable variation in the amount of mascle examined by difforent authors. During the years 1891 - 1906 pork intended for export to certain Zuropean countries was examined for trichinae by Federal meat in- 
spectors. The recognized procedure at that time was to examine three small samples, oech about the size of an oat grain. The laboratory mothods of the U. S. Armg roquire that only one sample, the size of a pea, be examinod. Hall and Collins and other parasitologists of the U. S. Public Health Service have used one gram portions in 211 of their surveys.

\section{Digestion-Beormann Technique}

Numerous modifications of the digestion-Baermam technique have been used. However, most methods are very similar to the one described by Hall and Collins (1937). The diaphragm is welghed, ground through an ordinary meat grinder and digested at $37^{\circ} \mathrm{C}$ in an artificial digestive jufce composed of 5 grams of pepsin and 7 cc. of concontrated hydroohloric acid per liter of water. The mixture is stirred every half hour with a glass rod for the first two or three hours and left in the inoubetor for 18 hours or longer. At the end of the digestion perlod most of the supermatant fluid is siphoned off and the romining fluid poured into a Beermann apparatus (a large funnel with an 80 mosh screen fitted into the top and closed at the base with a ploce of rubber tubing and a Hoffman clamp). After the fluid is allowed to stand one hour or longer, about $200 \mathrm{cc}$. are drawn off and examined under the low power objective of the microscope for trichInae larvae. These authors state that 3 ifters of arti- 
flclal gastric julce are required for proper digestion of samples weighing 50 grams or more.

Cameron (1938) used only $625 \mathrm{cc}$. of 0.2 per cent pepsin solution maintained at a $\mathrm{pH}$ of $1.0-2.0 \mathrm{by}$ the addition of HCl for the digestion of a 50 gram sample. It is very probable that Cameron used mechanical agitation to obtain proper digestion with this reduced amount of fluid though ho made no statement to that offect in his paper. Cameron also found that $0.05 \mathrm{gm}$. of papain alssolved in 150 ce. of normal saline could be substituted for the artificial gastric juice.

As with the direct method, the greatest amount of variation in the digestion technique has been in the amount of matorial examined. Hall and Collins (1937) and mang others making post-mortem examinations of human diaphragms aigested the entire diaphragm. The average weight was 98 grams. Queen (1931), McNaught and Anderson (1936), and others have used 50 grams of diaphragm in their survejs. Cameron in his studies of hog diaphragms digested only 10 gram portions. Hood and 01sen (1939) in a survor of trichinosis of swine in the Chicago area devised a system of mas digestion. They secured 20 gram samples, retained 10 grams and combined 10 grams with 19 other samples. The whole was then digested and examined. If positive the twenty wore then examined individually. 
The Skin Pest

At the present time the value of the intradermal test for the detection of trichinae infestations in swine is a controversial question. Schwartz (1941) stated that the reactions produced by the intracutaneous injection

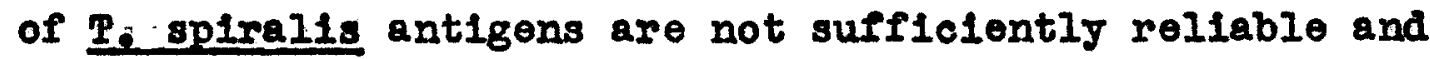
clear cut to be applicable to meat inspection. He based this statement on the results of over 11,000 tests conaucted by parasitologists of the Bureau of Animl Industry. Ilchterman and Glooman (1939) reportod the results of skin tests of 211 garbage fed hogs. These tests were checked by post-mortem examination of the diaphragms and 1t was found that 206 out of the 211 or 97 per cent had been diagnosed correctly. In additional tests made by these authors on 126 hogs, only two were diagnosed in correctly.

It may bo said that a rapid, spocific sicin test may soon be avallable but that mach more study is noeded bow fore this test can be included in the routine inapection of swine to be slaughtered. 
ADAPQATION OF METHODS 
The 1000 diaphragms studied in this survey wore examined by both the direct mforoscopic technique and the digestion-Beermann technique.

slight modifications were made in both mothods. In the direct microscople examination the facia was first removed and $1 / 2$ gram of mascle from varlous parts of the diaphragm was cut into small thin strips. Those strips were then placed in the "trichinae press" and examined under the low power objective of the microscope. The press used in this study consisted of two ploces of plate glass $2^{n} \times 10^{\prime \prime} \times 1 / 4^{\prime \prime}$ pressed together by a screw clamp at olthor and (F18. I). It was found that the transparency of masclo fibers obtained with this press was comparable to that obtained with the press described by Hall and Collins and Nolan and Bozicerich.

In the digestion-Beormann technique the tendenous and fatty portions of the diaphragm was put through an ordinary meat chopper. The sample was then digested in 3 liters of artificial gastric juice (5 grams pepsin and 7 cc. concentrated HCl por liter of water). The digestions were set up in a $37^{\circ} \mathrm{C}$ incubator fitted with oloctric agitators (Fig. II) so that the material was stirred constantly for 24 hours. At the end of this time the fluid was poured into a modified Baermann funnel (F1g. III). The Baermann apparatus consisted of a large funnel closed at the bottom 
by means of a plece of rubber tubing and a screw clamp. The top of the funnel was fitted with a double layer of gauze instead of the usual 80 mesh screen to retain any pleces of tendon and undigested flbers. The fluid was allowed to settle in the funnel for two hours and then portions were drawn off into Petri dishes and examined for larvae.

After 107 diaphragms had been examined it was declded to adopt the mas digestion procedure of Hood and 0lsen. Tendon and fat were removed from the diaphragms and 10 gram portions from each of 10 or 20 diaphragms were digested together and the remainder of the diaphragms were retained so that they might bo run individualiy if larvae were found in the sass digestion. In the course of this investigation it was found that complete digestion of the muscle could be obtained with less than 3 ilters of digestive fluid for 50 grams of sample. In the latter part of this work 1000 oc. of artificial gastric juice was used to digest 50 grams of diaphragm. In all probability the majority of workers in this fleld have overlooked the possibility of reducing the amount of digestive fluid because they reIled on occesional mamal agitation with a stirring rod instead of meohantcal agitation. 
RESULTS AND DISCUSSION 
of the 1000 diaphragms examined only two positives were found by the digestion mothod and one by the direct mloroscopic method. The one found positive by the direct examination was also positive by digestion. Thus the incidence of infestation in the group studied is 0.2 per cent. (Table I)

This discrepancy between the results of the direct and the digestion methods is to be expected. Hall and Collins found that elther method alone failed to detect trichinae in a certain number of cases. This view was supported by Nolan and Bozlcev1ch who stated that the microscopic method falled in a number of cases of light infestation. They concluded that though the digestion mothod was velueless in detecting dead trichinae it was reliable in detecting even very light infestations in which living worms were present.

The diaphragms were collected from four abattoirs in Loulsville, Kentucky over a perlod of nine months and therefore should represent a true cross-section of the incidence of trichine-infested pork reaching the Loulsville markets.

The incidence of infestation of swine with Te spiralis in Jefferson County is considerebly lower than the average Incidence of 1.5 per cent for the United States as est1mated by Schwartz. The correlation of trichinosis in swine 
with the predominant type of feeding in the various geom graphical sections of the United states, however, indicates that the 0.2 per cent infestation is very little lower than should be expected. Hall (1937) stated that the incidence of trichinosis in swine is approximately as follows: Pasture-raised swine mostly in the Middle West are free or practicaliy free from trichinae. The so-called grain fed swine in the Middie West are in reality a mixture of some pasture raised and some garbage fed swine and the mixture has an average infestation of about 1.5 per cent. Southorn swine have an average infestation of less than 1 por cent. Garbage fed hogs which are most mumerous along the southern part of the Pacific coast and the northern part of the Atlantic coast have an average incidence of about 5 per cent. The last group, and the one which has practically disappeared, is the offal fod hog which had the highest incidence of Infestation, about 18 per cent. The swine examined in the present study would be classed by Hall and others as grain fed for although wo were unable to determine the exact foeding, these swine were raised in a section of the country in which grain feeding predominates and were purchased for slaughter in the bellef that they had boen grain fod.

In Table II the results of this survey are compared with the results of several recent surveys of grain fed swine. It is evident that with such a small number of 
positives a difference of several tenths of a per cent is not significant.

The data summarized in Table III reveals that a number of workers have reported examining a series of hog diaphragms without finding any infested with $\mathrm{I}$. epiralis; thus further substantiating the bellef that the reported incidence of 0.2 per cent for Jefferson County is not unusualiy Iow. 
SUMMARY 
In the examination of 1000 diaphragms collected from swine slaughtered in Loulsville abattoirs, 2 were found infested with trichinae by the digestion-Beermann method and one of these was also found infested by the direct microscopic method, an incidence of 0.2 per cent.

Although the exact type of feed is unknown these swine may be classifled as grain-fed in conformity with the mothod used by Hall and Schwartz of clessifying swino accoraing to the type of foeding most prevelent in the section of the country in which the swine were raised. The incidence reported here is lower then the average of 1.5 per cent for the United States as estimated by Schwartz but many other investigators have reported similarIy low degrees of infestation. 
PABLE I

Incidence of Trichinella spiralis in the Diaphragms

of Swine from the Louisville Abattoire

No. found infested by

No. Exemined

505

241

139

115

Abatto1r \#4

Total

1000

\begin{tabular}{c} 
Direct $\begin{array}{c}\text { Digestion } \\
\text { Method }\end{array}$ \\
\hline
\end{tabular}

1

0

0

0

1
Per cent found infested by

Direct Digestion
Method Method

$\begin{array}{ll}0.2 \% & 0.4 \% \\ 0 & 0 \\ 0 & 0 \\ 0 & 0\end{array}$

$0.1 \% \quad 0.2 \%$ 
TABILE II

Incldence of Trichinosis in Grein-Fed Swine

as Indicated by Recent Surveys

\begin{tabular}{|c|c|c|c|c|c|c|}
\hline Author & Year & $\begin{array}{l}\text { Nethod of } \\
\text { Examination }\end{array}$ & $\begin{array}{l}\text { No. } \\
\text { Examined }\end{array}$ & $\begin{array}{c}\text { No. } \\
\text { Infested }\end{array}$ & $\begin{array}{l}\text { Per Cent } \\
\text { Infested } \\
\end{array}$ & Location \\
\hline Kerr and Jacobs & 1940 & digestion & 566 & 3 & 0.5 & Califormia \\
\hline Schwartz & 1936 & digestion & 4740 & 53 & 1.0 & \\
\hline Schwartz & 1940 & digestion & 4461 & 33 & 0.76 & \\
\hline Hood and 0lsen & 1939 & digestion & 500 & 2 & 0.4 & Chicago, Ill. \\
\hline Adams & 1942 & $\begin{array}{l}\text { microscopic } \\
\text { and digestion }\end{array}$ & 1000 & 2 & 0.2 & Louieville, Ky. \\
\hline
\end{tabular}


TABLE III

Incidence of Trichinosis in Swine

\begin{tabular}{|c|c|c|c|c|c|c|c|}
\hline Author & Year & Type of Feed & $\begin{array}{c}\text { Method of } \\
\text { Exam1nation }\end{array}$ & $\begin{array}{l}\text { No. } \\
\text { Examined }\end{array}$ & $\begin{array}{l}\text { No. } \\
\text { Infested }\end{array}$ & $\begin{array}{l}\text { Per Cent } \\
\text { Infested }\end{array}$ & Location of Survey \\
\hline Mark & 1881 & $\begin{array}{l}\text { grain and } \\
\text { garbage }\end{array}$ & microscopic & 500 & 10 & 2.0 & Chicago, Illinois \\
\hline Mark & 1888 & $\begin{array}{l}\text { garbage } \\
\text { offal }\end{array}$ & microscople & 3064 & 391 & 12.86 & Boston, Massachusetts \\
\hline Mark & 1888 & garbege & microscopic & 234 & 42 & 17.95 & Massachusetts \\
\hline Calvin & 1890 & offal & & & & $8-10 \%$ & Iowa \\
\hline Calvin & 1890 & grain & & & & $\begin{array}{l}\text { practical- } \\
\text { ly none }\end{array}$ & Iowa \\
\hline Federal & 1898 & & microscopic & $8,257,928$ & & $1.5 \%$ alive & Entire U. S. \\
\hline Inspection & 1906 & & & & & $1.0 \%$ dead & \\
\hline Billings & 1880 & $\begin{array}{l}\text { grain and } \\
\text { cooked meat }\end{array}$ & microscopic & 28 & 0 & 0 & Massachusetts \\
\hline B1llings & $\begin{array}{l}1879- \\
1881\end{array}$ & $\begin{array}{l}\text { garbage offal } \\
\text { and grain }\end{array}$ & & 8773 & 347 & 4.0 & Boston, Massachusetts \\
\hline Deverson & 1881 & & & 4146 & 0 & 0 & Southern U. S. \\
\hline Deverson & 1881 & & & 241 & & 0.83 & Louisville, Kentucky \\
\hline Deverson & 1881 & & & 5400 & 22 & 0.4 & New Orleans, Louisiana \\
\hline
\end{tabular}




\section{TABTE III (Con't.)}

Incidence of Trichinosis in Swine

\begin{tabular}{|c|c|c|c|c|c|c|c|}
\hline Author & Year & Type of Feod & $\begin{array}{l}\text { Method of } \\
\text { Examination }\end{array}$ & $\begin{array}{l}\text { No. } \\
\text { Exenined }\end{array}$ & $\begin{array}{c}\text { No. } \\
\text { Infested }\end{array}$ & $\begin{array}{l}\text { Per Cent } \\
\text { Infested }\end{array}$ & Location of Survey \\
\hline Deverson & 1881 & & & 529 & & 3.4 & St. Louis, Missouri \\
\hline Detmers & 1883 & $\begin{array}{l}\text { pasture } \\
\text { raised }\end{array}$ & & 100 & 0 & 0 & Indiana \\
\hline Detmers & 1883 & grain & & & & 2.0 & Chicago, Illinois \\
\hline Simpson & $\begin{array}{l}\text { ante } \\
1884\end{array}$ & & & 30 & 0 & 0 & Atlenta, Georgia \\
\hline St eger & $\begin{array}{l}\text { ante } \\
1884\end{array}$ & & & 180 & 0 & 0 & Nashville, Tennessee \\
\hline Meyer & $\begin{array}{l}\text { ante } \\
1884\end{array}$ & & & 330 & & 0.6 & San Antonio, Texas \\
\hline $\begin{array}{l}\text { Atwood and } \\
\text { Belfield }\end{array}$ & 1886 & grain & & & & 2.0 & Chicago, Illinois \\
\hline $\begin{array}{l}\text { Harding and } \\
\text { Robbins }\end{array}$ & 1874 & $\begin{array}{l}\text { garbage offal } \\
\text { and grain }\end{array}$ & & & & 16.3 & Dearborn Co., Indiana \\
\hline $\begin{array}{l}\text { Harding and } \\
\text { Robbins }\end{array}$ & $\begin{array}{l}1874 \\
1884\end{array}$ & $\begin{array}{l}\text { garbage offal } \\
\text { and grain }\end{array}$ & & & & 6.5 & Dearborm Co., Indiana \\
\hline
\end{tabular}


TABLE III (con't.)

Incidence of Trichinosis in Swine

Author Yeer Type of Feed Exemination Examined Infested Infested Location of Survey

\begin{tabular}{|c|c|c|c|c|c|c|c|c|}
\hline $\begin{array}{l}\text { McNaught and } \\
\text { Zapata }\end{array}$ & 1941 & garbage & $\begin{array}{l}\text { microscopic } \\
\text { and digestion }\end{array}$ & 495 & 20 & 4.04 & San Francisco, & California \\
\hline $\begin{array}{l}\text { Hobmai er } \\
\text { and Gelger }\end{array}$ & 1938 & garbage & digestion & 92 & 13 & 1.4 & San Francisco, & California \\
\hline $\begin{array}{l}\text { Hobmaier } \\
\text { and Geiger }\end{array}$ & 1938 & unknowm & digestion & 108 & 0 & 0 & San Francisco, & Celifornia \\
\hline $\begin{array}{l}\text { Kerr and } \\
\text { Jacobs }\end{array}$ & 1940 & garbage & digestion & 502 & 30 & 6.0 & California & \\
\hline $\begin{array}{l}\text { Kerr and̄ } \\
\text { Jacobs }\end{array}$ & 1940 & $\begin{array}{l}\text { other than } \\
\text { garbage or } \\
\text { grain }\end{array}$ & digestion & 1532 & 14 & 1.0 & Califormia & \\
\hline Schwartz & 1938 & garbage & digestion & 2847 & 286 & 10.0 & & \\
\hline
\end{tabular}


TABLE III (con't.)

Incidence of Trichinosis in Swine

\begin{tabular}{|c|c|c|c|c|c|c|c|}
\hline Author & Year & Type of Foed & $\begin{array}{l}\text { Method of } \\
\text { Examination }\end{array}$ & $\begin{array}{l}\text { No. } \\
\text { Exemined }\end{array}$ & $\begin{array}{c}\text { No. } \\
\text { Infested }\end{array}$ & $\begin{array}{l}\text { Per Cent } \\
\text { Infested }\end{array}$ & Location of Survex \\
\hline Schwart z & 1938 & $\begin{array}{l}\text { cooked } \\
\text { garbage }\end{array}$ & digestion & 1860 & 11 & 0.59 & \\
\hline Schwartz & 1940 & grain & digestion & 4461 & 33 & 0.75 & \\
\hline Schwartz & 1940 & garbage & digestion & 5312 & 136 & 2.6 & \\
\hline $\begin{array}{l}\text { Hood and } \\
\text { Olsen }\end{array}$ & 1939 & grain & digestion & 500 & 2 & 0.4 & Chi cago, Illinois \\
\hline $\begin{array}{l}\text { Barrett and } \\
\text { Sears }\end{array}$ & 1938 & & & 194 & 0 & 0 & Melchigan \\
\hline Cemeron & 1938 & & digestion & 729 & 15 & 2.05 & Canada \\
\hline Cameron & 1939 & $\begin{array}{l}\text { cooked } \\
\text { garbag } \theta\end{array}$ & $d i_{\text {Gestion }}$ & 2000 & 15 & 0.75 & Canada \\
\hline Cameron & 1940 & & digestion & 995 & 2 & 0.2 & Canada \\
\hline
\end{tabular}




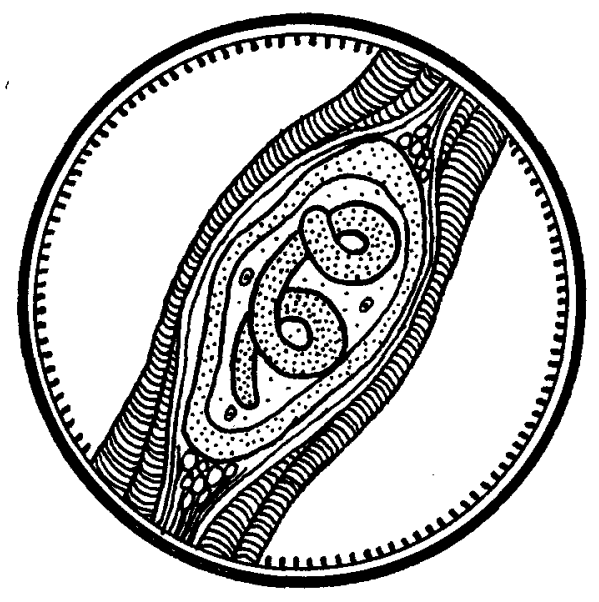

(a)

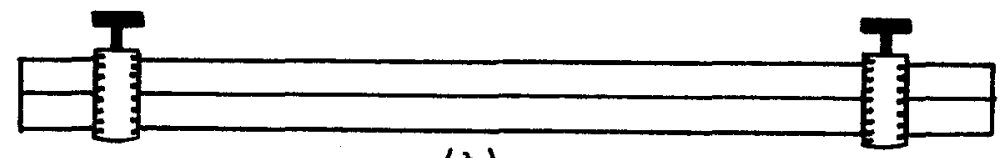

(b)

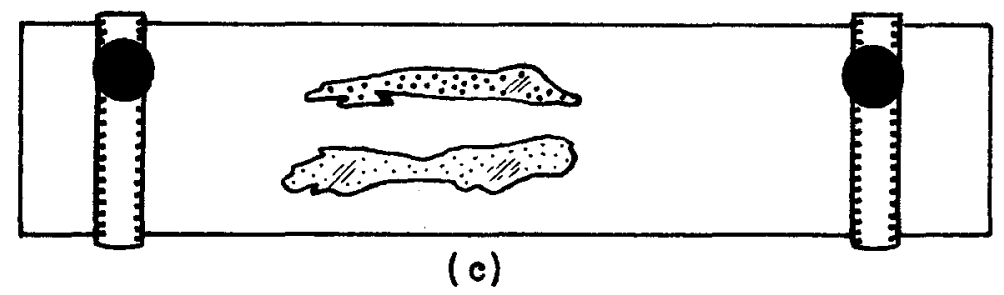

FIGUFE I

(a) Larvae of Trichinella spiralis

(b) Trichinge Press (sice view)

(c) Trichinae Press (top view) 


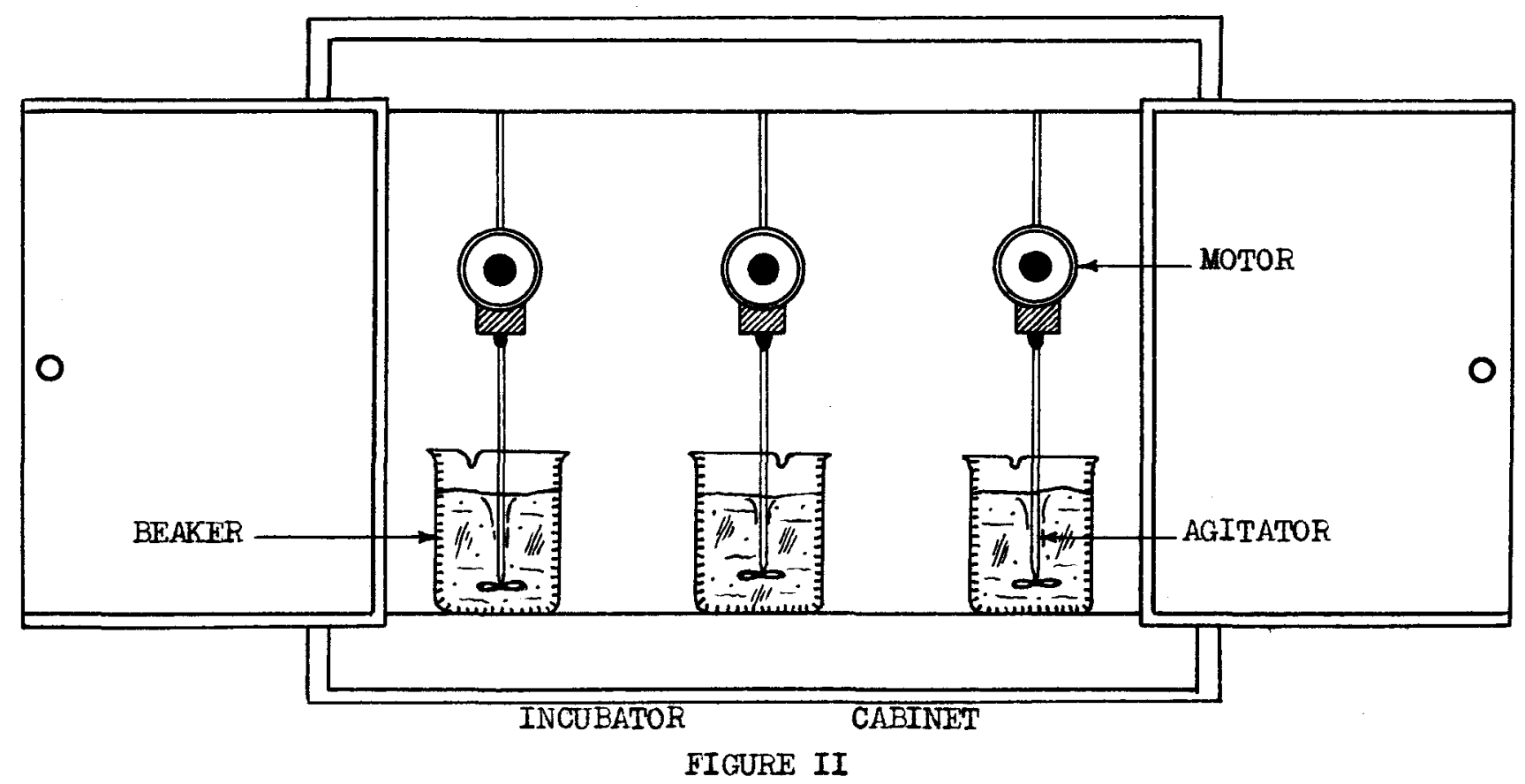

DIGESTION APPARATUS 


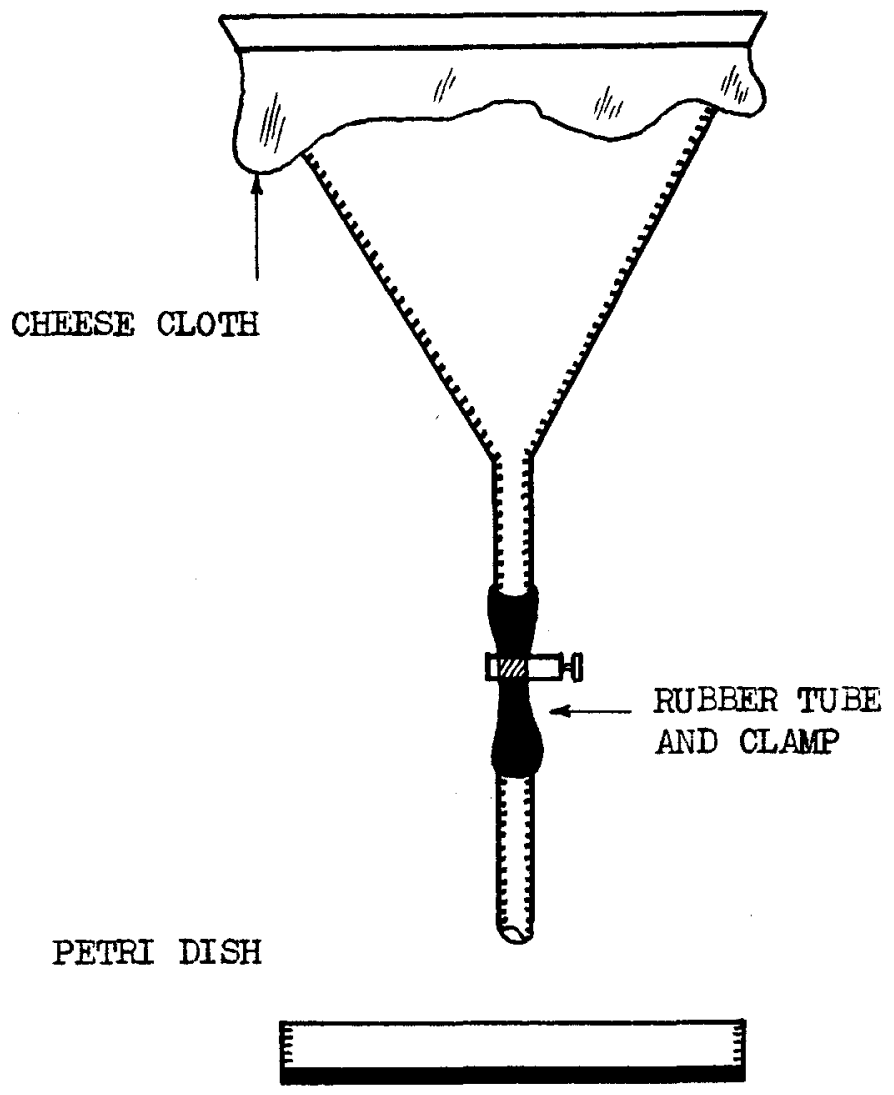

FIGURE III

BAEPMANN APPARATUS 
REITEREITCES 
References

Anongmous: "The Lest Ner D1sease" Lancet, 1, 16 (1866)

Barrett, C. D. and RIchard Sears: TThe Epldemiology of Trichinosis"

Amorican Journel of Public Health, 28, 706 - 717 (1938)

Calvin, S.: Bulletin of the Laboratory of Hatural History State University, Iow, $2,85-89$ (1890)

through Hall, Naurice C.: "Studies on Trichinosis. IV The Role of the Garbege-fed Hog in the Production of Human Trichinosis." United States Public-Hodith Roports, 52, 873-886 (193'

Cameron, Thomas W. M.: "Investigations on Trichinosis in Canada. I A Preliminary survey of the Incidence of Trichinella spiralis in Hogs in Eastern Canada". Ganadian Journal of Research Section "D Zoological 8010 2008, 16, $.89-92$ (1939)

Cameron, W. Mo: "Irvestigations on Trichinosis in Caneda. II A Further Study of the Inclaence of Prichineila spiralis in Hogs in Eastern Canada". capacian Journal of Research Sootion "D" Zoolosical Sclonces, 11, $151-153$ (1939)

Cameron, W. H.: "Investigations on Trichinosis in Canada. III on the Incidence of Trichinosis in Garbagenfed Hogs". Ganedian Journal of Research Soction "D" Z00 log 10 al sclences, 18, 83-85 (1940)

de Pletra Sante, Prosper: "Trichine ot Trichinoso aux Etats-Unis". Paris 4I pp (1884) through Hali, Maurice C.: "Studies on Trichinos1s IV The Role of the Garbage-fod Hog in the Production of Human Trichinosis". United-States-Public-Health Reports, 52, 873-886 (193\%)

Hall, Maurice C. and Benjamin J. Collins: "Studied on Trichinosis. I The Incldence of Trichinosis as Indicated by Post-mortem Examinations of 300 Dlaphragms". United States-Public-Health Reparts, 52, 468-490 (1934)

Hal1, Maurice C.: "Studies on Trichinosis. IV The Role of the Garbage-fod Hog in the Production of Human Trichinosis". Initod States Public Hoalth Reports, 52, 873-886 (193') 
H1lton, J.: "Notes of a Peculiar Appearance Observed in Human lascle, Probably Depending upon the Formation of Small Cyst1cerc1". Eondon Medical Gazette, 11, 605 (1833) through Blumer, Goorge: "Some Remarks on the Early History of Trichinosis" (1822-1866). Yale Journal of B10logr and Medicine, 11, 581-588 (1938-1938)

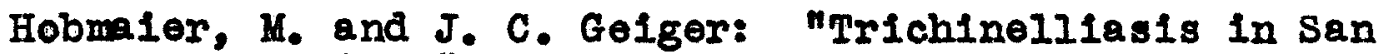
Francisco". American Journel of Public Health, 28. $1203-1211$ (1838)

Hood, Marion and S. W. Olsen: Mrichinosis in the Chicago Area." Amoricen Journal of Hrglene Section "D" 29, $51-56$ (1939)

Kerr, K. B. and L. Jacobs. "Certain Aspects of Trichinosis situation in California" (1940) through "Heat for Millions". Report of the New York State Iriohinosis Commission, and odition, LegisIQtive Document, 5z, $282 \mathrm{pp}$ (1941)

Kerr, K. B., Leon Jacobs and Eugenie Cuv1111er: "Studies in Trichinosis. XIII The Incldence of Human Infection with Trichinac as Indiceted by Post-morten Examination of 3000 Diaphragms from Washington, D. C. and 5 Eastern Seaboard Cit1es". Enited States-Public Health Reports, 56, 836-855 (i94i)

Leidy, J.: Proceedings of the Academ of Natural Sclence. Philadelphia, 3 , I01 (1846) through Blumer, George: "Some Remarks on the Early H1story of Trichinosis" (1822-1866). Yalo-Journe1 of Blologr and Medielne, 11, 581-588 (1939)

Ilchterman, Abraham and Irvin Klooman: "Dotection of Trichinelia Infestation in Hogs by the Intradermal Test". Amertcan Journal of Public Hoalth, 29, 1098-1102 (1939)

Ipckart, R.: "Untersuchungen uber Trichina spiralis" C. F. Winter'sche Verlagshandlung, Ilepzig and He1delburg (1860) through Blumer, George.: some Remarks on the Early History of Trichinosis" (1822-1866) Yale-Journal of Blologx and Medicine, 1I, 581 (1939)

MeNaught, James B. and Eugene V. Anderson: "The Incidence of Trichinosis in San Francisco". Journal of tho American MedLcel-Associetion, 107, 1446-1448 (1836) 
Moriaught, James B. and Emerson M. Zapata: "Incidence of Trichinelia spiralis in Garbage-fed Hogs in San Franc1sco". Proceedings of the Society of Experimental Biologr and Ledielne, $45,701-704$ (1940)

Mark, E. I.: "Trichinae in swine" 20th Annual Report of the Hassachusetts state Board of Health for 1888 Boston $111-134$ (1889)

"Meat for Millions". Reports of the Now York State Trichinosis Commission, and edition Tegislativo Document, 52, $282 \mathrm{pp}$ (1941)

Nolan, M. O. and John Boricerich: "Studies on Trichinosis $V$ The Incidence of Trichinosis as Indicated by Postmortem Examinations of 1000 Diaphragms." Public Health Reports, 53, 652-653 (1938)

owen, R.: "Description of a Microscopic Bntozoan Infesting the Mascle of the Human Body". Proceedings of the Zoological society Iondon 323 (1835) through Blumer, George: "Some Remarks on the Early History of Trichinosis" (1822-1866). Yalo-Journal of Blolog and Medicine, 11, 581-588 (1939)

Paget, James: "On the Discovery of Trichina" Eancet, I, 269 ( 18660

Queen, F. B.: The Provalence of Human Infection with Prichinelia spiralig Journel of Parasitologr 18, $128 \mathrm{pp}$ (1931)

Schrartz, Benjamin: Anmal Roport of the Bureau of Animal Industry - United States Department of Agriculture 53-60 (1936)

Se hwartz, Benjamin: Annual Report of the Bureau of Animel Industry - United states Department of Agriculturo $75-85$ (1938)

Schwarte, Benjamin: "Tho Trichinosis situation in the United States" Pablication of the Bureau of AnimaI Industry United States Departmont or Agriculture mimeographod $8 \mathrm{pp}$ (1940)

Schwartz, Benjamin: "Requisites for a Practical Intracutaneous Test for the Detection of Trichinae Infections in Swine". Journal of the American Voterinary Modicine Assoclation 99 465-467 (1941) 
simmons, James s. and Cleon J. Gentzkom: "Laboratory Methods of the United States Army". 894, 4th edition, Lea and Ferblger, Philadelphla (1935)

Tiedemann, F.: Froriep's-Notizen, 1, 64 (1822) through BIumer, George: "Some Remarks on the Early History of Trichinosis" (1822-1866). Tale Journal of Blolosy and Hedicine, 21 581-588 (i939)

Virchow, R.: "Darstellung der Lehre von den Trichinen". Georg Relmer, Berlin (1864) through Blumer, George: "Some Remarks on the Early History of Trichinosis" (1822-1866). Yale Journal of Blology and Medicine, 11, 581-588 (1939)

Zenker, F. A.: "Uber die Trichinenkrankheit des Menschen". Virchow's Archip of path. Anat., 18, 561 (1860) through BIumer, Goorge: "Some Remarks on the Early History of Trichinosis"(1822-1866). Yale Journal of Blology and Medicine, $11,581-588$ (1939) 